\title{
DaVinci Academie's Travel Journey Visual Design
}

\author{
Angelina Patricia Handojo 1,2 \\ ${ }^{1}$ Art and Technology, Faculty of Academie Creatieve Technologie, Saxion University of Applied Sciences, \\ M. H. Tromplaan 28, 7513 AB, Enschede, The Netherlands \\ ${ }^{2}$ Desain Komunikasi Visual, Fakultas Seni dan Desain, Universitas Kristen Petra, \\ Jl. Siwalankerto 121-131, Surabaya \\ Email : angelinapatriciah@gmail.com
}

\begin{abstract}
DaVinci is an educational company that has two backing departments. One is aimed at children, namely DaVinci Publisher, and the other is for adults, namely DaVinci Academie. DaVinci Publisher is a department that offers education methods for children, and its vision is to develop kids with their educational products and materials about a way of thinking and learning. DaVinci Publisher has already gotten products to support children's education from the design of the visuals and supporting media like textbooks, workbooks, binders, etc. However, DaVinci Academie still has nothing to support the education for adults and its target audiences who consist of directors, manager teachers, etc., and do not know about the messages that it carries. Finding the requirements to produce a suitable design of the visuals and the supporting media are needed to support the messages within a travel journey concept given by DaVinci Academie.
\end{abstract}

Keywords: Graphic design, traveling, visual design, communication of messages.

\begin{abstract}
Abstrak
DaVinci adalah perusahaan pendidikan yang memiliki dua departemen pendukung. Satu ditujukan untuk anak-anak yaitu Penerbit DaVinci, dan yang lainnya untuk orang dewasa yaitu DaVinci Academie. Penerbit DaVinci adalah departemen yang menawarkan metode pendidikan untuk anak-anak, dan visinya adalah mengembangkan anak dengan produk dan materi pendidikan tentang cara berpikir dan belajar. Penerbit DaVinci sudah mendapatkan produk untuk menunjang pendidikan anak mulai dari desain visual dan media pendukung seperti buku teks, workbook, binder, dll. Namun, DaVinci Academie masih belum memiliki apa-apa untuk menunjang pendidikan bagi orang dewasa dan target audiensnya yang terdiri dari direktur, guru manajer, dll, juga tidak tahu tentang pesan yang dibawanya. Menemukan kebutuhan untuk menghasilkan desain visual yang sesuai dan media pendukung diperlukan untuk mendukung pesan-pesan dalam konsep perjalanan perjalanan yang diberikan oleh DaVinci Academie.
\end{abstract}

Kata kunci: Desain Grafis, Travelling, Desain Visual, Komunikasi Pesan.

\section{Introduction}

DaVinci is an educational company that has two backing departments, which are DaVinci Publisher for children, and DaVinci Academie for adults. DaVinci has been established since 15 years ago, with DaVinci Publisher as its' first department. DaVinci Publisher is a department that offers the methods for children's education, and its' vision is to develop kids with their educational products and materials about a way of thinking and learning.

Furthermore, DaVinci Publisher has already gotten products to support children's education, like the design of the visuals and supporting media like theory books, workbooks, binders, etc.

On the other hand, to support adults with the same mindset and vision, DaVinci expanded their department in the beginning of 2015 with DaVinci
Academie. DaVinci Academie also offers many kinds of trainings and programs, with Person- al Leadership and Personal Development as the main essence. Moreover, the target audiences of DaVinci Academie are consisted of teachers, directors, managers, front and back developers, education developpers, etc.

Meanwhile, since DaVinci Academie has been setting up only for a year, DaVinci also realizes that its second department should be optimized more. DaVinci also recognizes that its second department still has nothing to support the education for adults, like what DaVinci Publisher already has. DaVinci Academie has only presentations, verbal languages and handouts with pieces of papers to support their education in the trainings and programs, like shown in the picture below. This photo is taken during the observation in DaVinci Academie's training and program. 
Even more, the target audiences of DaVinci Academie also still do not know and understand about the messages that DaVinci Academie have, which is to introduce and give lessons in Personal Leadership and Personal Development. This happens due to the fact that DaVinci also has not introduced the messages to the target audiences.

Therefore, to optimize the training and programs of DaVinci Academie, DaVinci wishes to have something to support its second department's trainings and programs, like creating the design of visuals or the media. On top of that, DaVinci also wants that the target audiences understand about the messages, so they can have a clear vision that the main core of DaVinci Academie's trainings and programs is about the Personal Leadership and Personal Development.

In addition to this, DaVinci wishes to have the design of the visuals and the media that could be used as effective devices to communicate the messages of DaVinci Academie to the target audiences. For these reasons, DaVinci has an idea for the concept of the design of the visuals, which is based on a travel journey. This happens on DaVinci's belief that Personal Leadership and Personal Development are like a never ending journey where people can discover everything about themselves, with all kinds of learning and experiences along the adventures.

\section{Research Methods}

The graduation assignment is completed through a desk research method, by doing researches, observations, and distributing the questionnaires for DaVinci Academie's target audiences.

a. A Desk Research Method

Find the information through the internet and literature studies in order to gain many knowledge and inspirations for this graduation assignment.

b. Observations

The observations are done based on the behaviour of the target audiences during DaVinci Academie's training and programs and the programs itself.

c. Distributed Questionnaires

The questionnaires are distributed to the target audiences in order to know the answer based on them, which will support the production of this graduation assignment.

\section{Analysis Methods}

The method is using a desk research method, by doing research through the internet and literature studies, doing observations, and distributed questionnaires. The uses of these methods aimed to know the requirements of the design of the visuals in order to support or communicate the messages of DaVinci Academie to the target audiences.

\section{Purpose of Graduation Assignment}

The purpose of this graduation assignment is to create the design of the visuals in order to support and communicate the messages of DaVinci Academie.

The purpose of this graduation assignment are divided:

- In order for the target audiences to know about the messages of DaVinci Academie.

- In order for the target audiences catch the essence of DaVinci Academie's training and programs.

- In order to develop DaVinci Academie more, since it is considered as a new comer.

- In order for DaVinci Academie to have the suitable design of the visuals for its target audiences.

\section{Graduation Assignment Concept}

Since DaVinci believes that travelling is a journey that will give new experiences for people and gain ore knowledge, so they agreed at the first time that the concept for this graduation assignment is about travelling.

Based on Masaray (2011), travelling is a journey that would give some contribution in individual's development by gaining new experiences, developing a new way of seeing things, getting inspiration, having a global mindset, and having new connections with other people all over the world (Licastro, n.d).

The target audience's mindsets about a travel journey concept, according to the collected data, were about a way to grow, to explore everything out of the comfort zone, to explore the world and adventures, to see new things, to learn about new cultures, to be away from home, to be free and relaxed. Their mindsets were similar with the meaning of what the travel journey was about. They also agreed that travelling had influences to the development of a person. Therefore, it would be easier to create the design of the visuals that communicate the messages of DaVinci Academie using the travel journey concept, since travel journey (the concept) was associated with individuals' development (the messages).

Furthermore, since DaVinci Academie's target audiences did not know about the exact messages 
that DaVinci Academie's carry, therefore, through the design of the visuals based on the travel concept, the messages will be communicated to the target audiences.

\section{Chosen Color}

The colors used for the design of visuals were dominated by blue, green, brown, and red. The reasons these colors were selected because the meanings of these colors had correlation with the messages, the target audiences' behaviors during the observations and the trainings and programs of DaVinci Academie. For the blue color, it can also reduce stress. It is a color that means to be succeed in whatever effort it pursues. Since DaVinci Academie focuses on the trainings and programs for the personal leadership and personal development of adults, DaVinci Academie shares the knowledge and intelligence to the target audiences and these are correlated to the meaning of the colors.

Green symbolizes environment, growth, freshness, power, hope, peace, relax, ambition, renewal, adventure, and energy. Green also stands for the lack of experience and the needs to grow. Furthermore, the meaning of green, which is relaxed, matches with the behavior of the target audiences. Green color also suits the concept of travelling, since when someone travels, he will experience a new environment. Thus, once the target audiences have understanding about the materials, they will know about something new and learn different knowledge for their lives, which will be useful for them in the future.

Moreover, brown signifies hard working, reliable, calmness, being responsible and serious, while red illustrates leadership qualities, motivates to take actions, promotes ambition and power, and gives confidence. This color matches to the messages of DaVinci Academie, which is about the personal leadership and personal development.

\section{Chosen Typeface}

The typeface is using the Sans Serif, which is the Apex Book.

\section{ABCDEFGHIJKL MNOPQRS TUVWXYZ

Picture 1. Font Apex Book

\section{Chosen Type of Visuals}

The type and visuals that will be used in the design of the visuals is based on the distributed questionnaires to the target audiences. Some of the target audiences would rather choose photographs, while the rest showed interest in illustrations. The total results of the target audiences' preference percentage were equal, namely $50 \%$ and $50 \%$, respectively. Therefore, the type and visuals used for the design of the visuals were combined between photographs and illustrations.

\section{The Design of the Visuals}

The design of the visuals is made fun, which reflects the behavior of the target audiences, based on the colors and the visual elements. From the selection of the target audiences, the main media is chosen where the main design of the visuals is implemented. In the next page, there is a picture of the main design of the visuals for this graduation assignment.

For the design of the visuals of the supporting media, it is more likely similar to the main design, since the style and the implementation used are the same to achieve uniformity. Moreover, in every design of the visuals, there is a visual element of the airplane, which carries a magnifying glass on the top of it, flying it over to the finish line, across many countries or many places. This means that the airplane delivers the messages of DaVinci Academie until it reaches the finish line. The finish line is the goal of DaVinci Academie, which helps the target audiences to reach their goals in participating the Personal Leadership and Personal Development education from DaVinci Academie's trainings and programs.

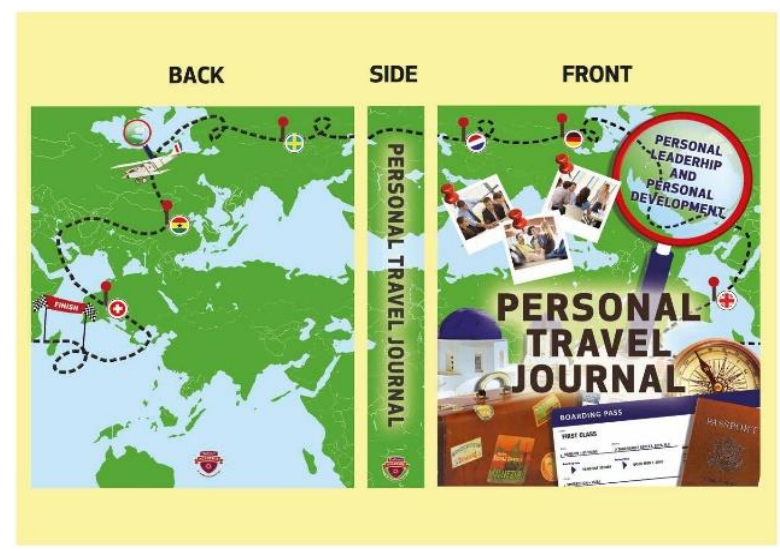

Picture 2. DaVinci Academie's Main Design of the Visuals

\section{DaVinci Academie's Main Media}

The media of DaVinci Academie will be distributed to the target audiences during the trainings and programs. However, online brochure is the only media given before the trainings and programs start. 


\section{Main Media (Binder)}

The main media of DaVinci Academie's tranings and programs is chosen based on the selections of the target audience. Binder has the highest amount of votes among the other media. Therefore, the miscellaneous designs for the binder's accessories is created, such as file dividers.

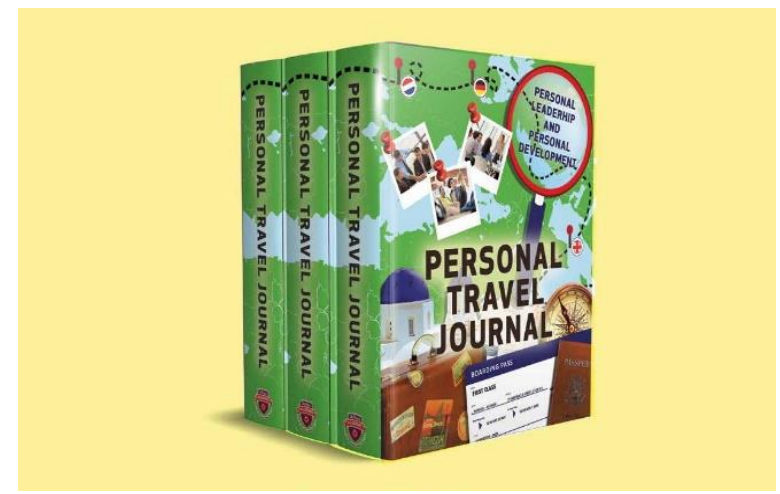

Picture 3. DaVinci Academie's Main Media (Binder)

\section{Main Media (File Dividers)}

All of the file dividers has four holes on the left sides and is put inside the binder. There is a line in the second file dividers that connects the line to every page. This represents the journey of the training and programs, from the beginning until it is finished. Furthermore, the map of the world is also connected to one another, when the file dividers are placed next to each other.

The visual elements used in the file dividers are still based on the survey. Value and emphasis also applied in the visual elements for the file dividers. Next, there are quotes used in the file dividers about the personal leadership and personal development. This is contemplated to strengthen the messages to the target audiences, because these quotes also gives account of the messages of DaVinci Academie.

As shown below, the quotes are put differently on the right side in some pages and on the left page in the other pages. The quotes are put in such manner because it is correlated with the map of the world to make the target audiences easy to read the quotes. Thus, the position of the quotes depends on the direction of the map itself.

The dark blue color used for the quotes because all of the quotes are represented personal leadership and personal de- velopment, and the meaning of dark blue itself is intelligence and knowledge. Therefore, since personal leadership and personal development are the materials and the essence of DaVinci Academie's the trainings and programs, therefore, this implementation aims for the target audiences to develop and gain new knowledge and intelligence through the lessons.

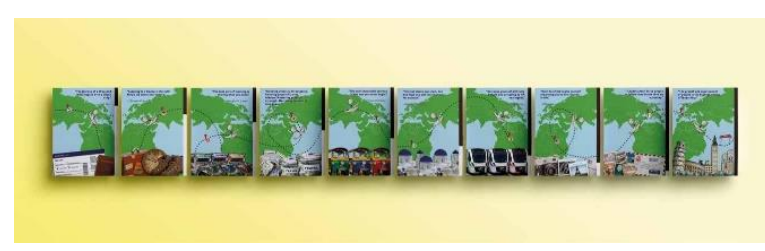

Picture 4. The File Dividers without the Table of Content

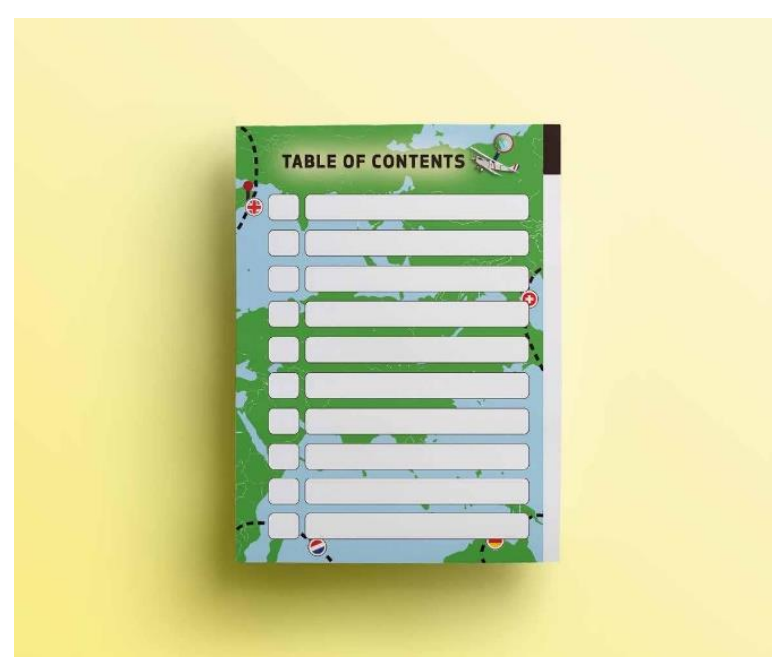

Picture 5. The File Dividers page 1

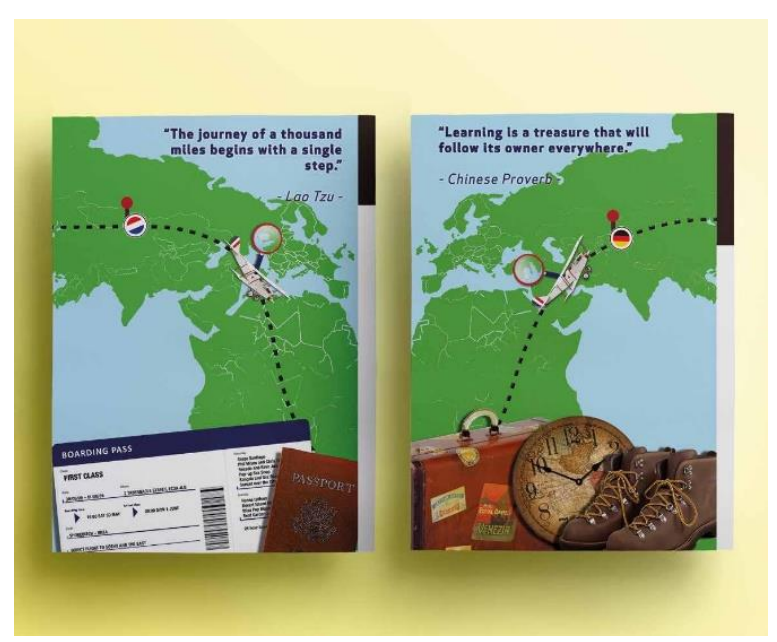

Picture 6. The File Dividers page 2 and 3

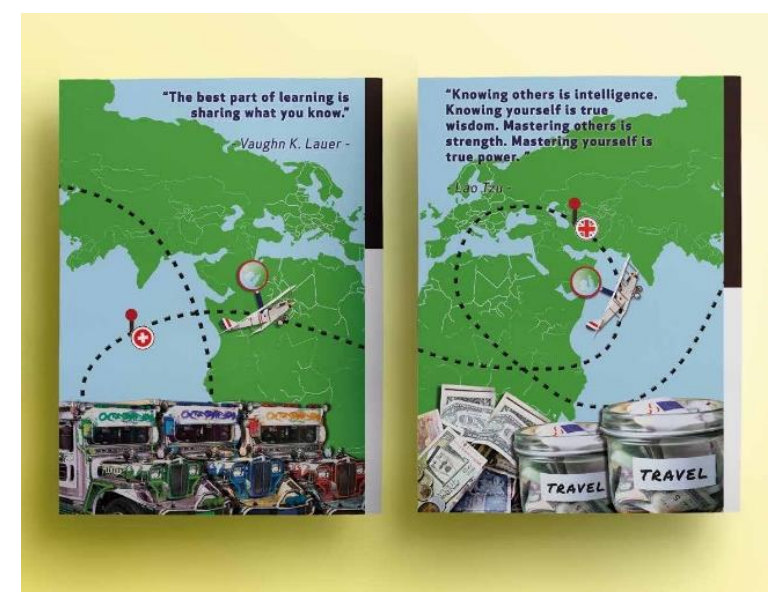

Picture 7. The File Dividers page 4 and 5 


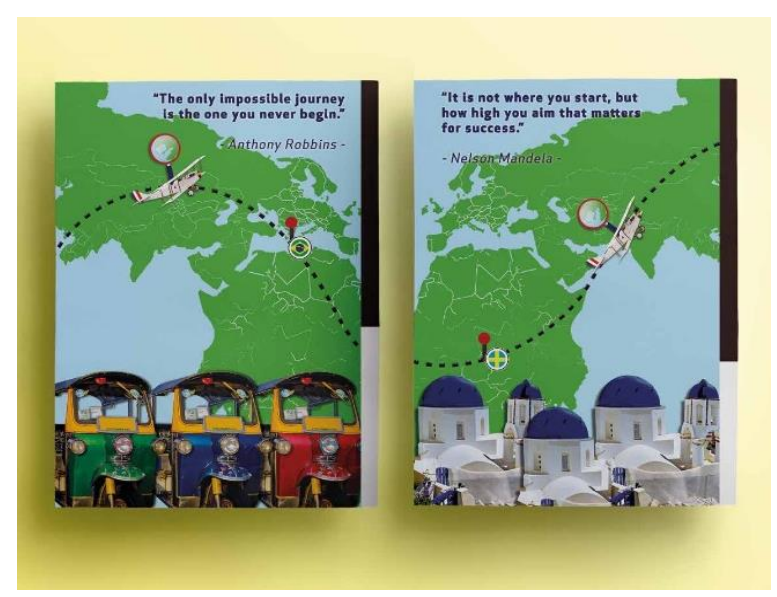

Picture 8. The File Dividers page 6 and 7

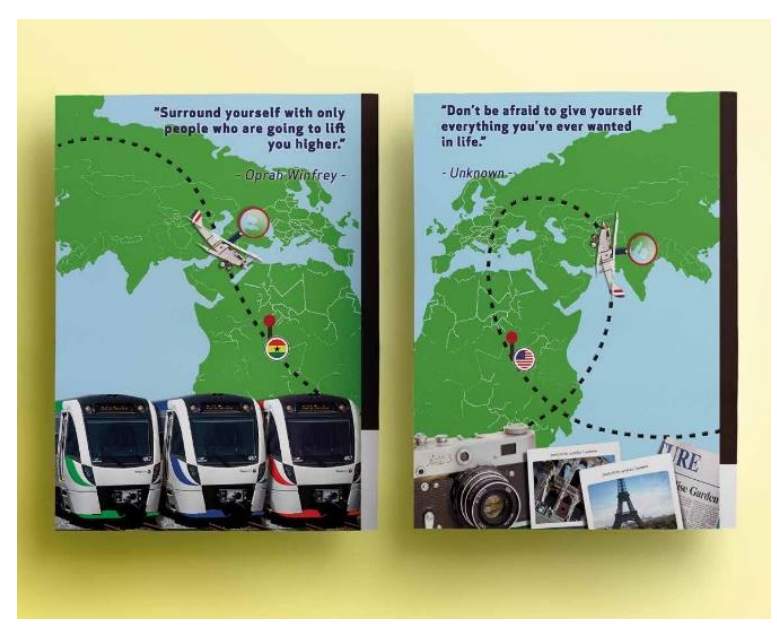

Picture 9. The File Dividers page 8 and 9

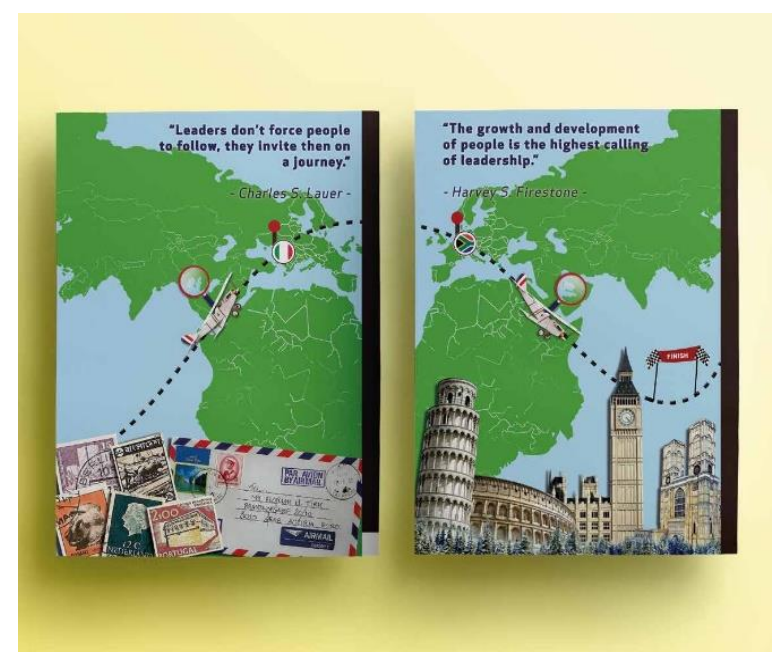

Picture 10. The File Dividers page 10 and 11

\section{DaVinci Academie's Supported Media}

According to the target audience's selections, some supporting media, such as notes or the paper sheets and the brochure are made. These supported media chosen based on the two highest amounts of votes after binder.

\section{Papersheets}

The design of the paper sheets is created with the same style as the main media: each has the four holes, and is put inside the binder so that the target audiences could take notes on it.

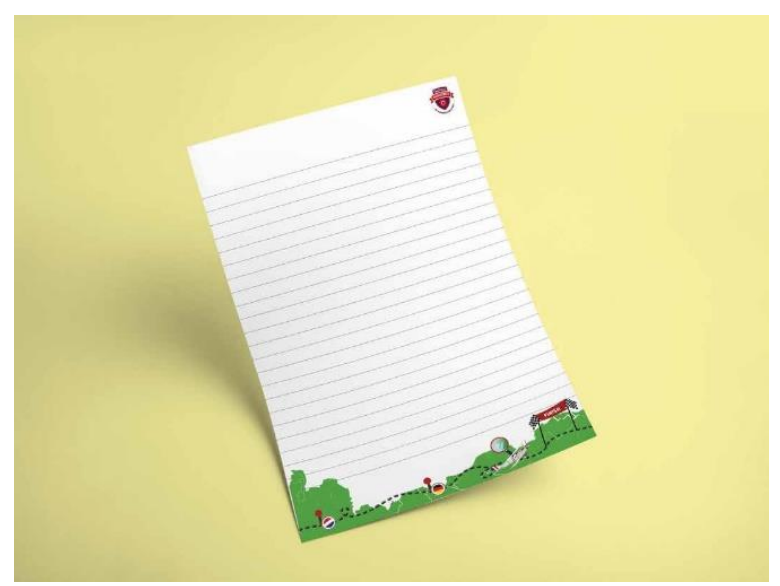

Picture 11. Papersheets

\section{Brochure}

The brochure is not a printable brochure, whether it is an online brochure. This brochure is used to explain the summary of the trainings and programs. This online brochure is utilized until the end of the trainings and programs in one academic year. It also has the same concept and style as the other media. However, the title of the brochure and the content inside are flexible due to changes.

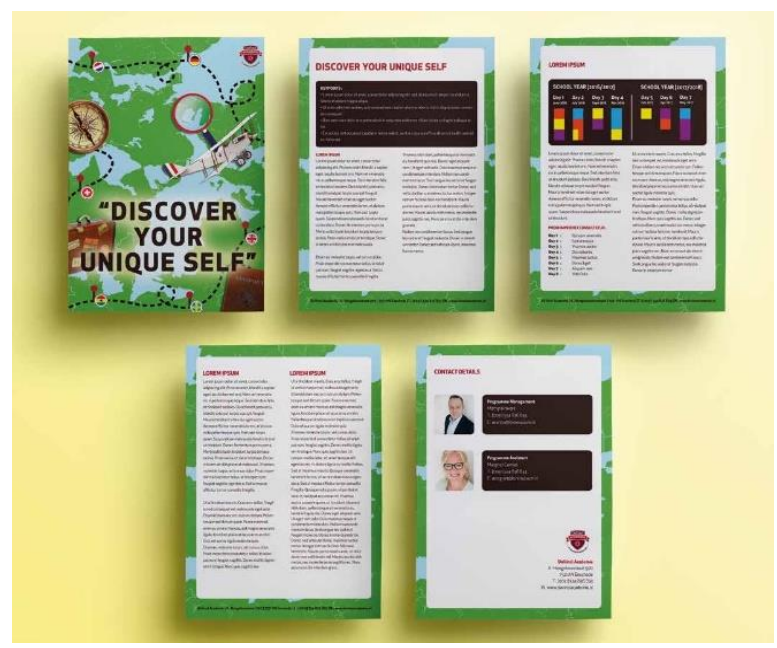

Picture 12. Online Brochures

\section{Name Board and Name Batch}

The design for the name board and the name batch are used the same style like the other media and put on their clothes and on their desk, respectively, for their next trainings and programs. However, this media is not something in the demand lists of the 
target audiences, whether they were born purely based on the observations. Thus, it is recommendable for DaVinci to have these media because it would help the teacher to know each of the participants' easily.

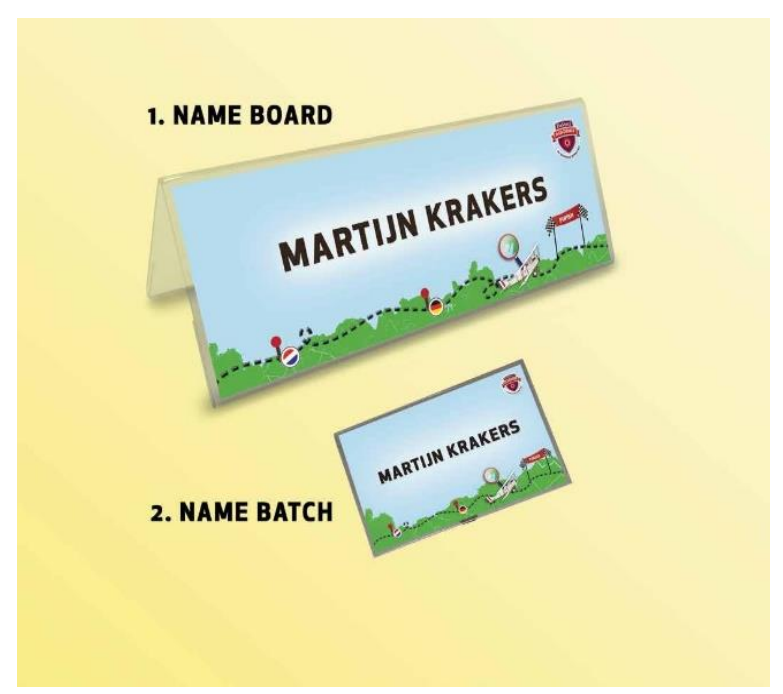

Picture 13. Name Board and Name Batch

\section{Conclusion}

According to the analysis and the gathered data, the target audiences were choosing illustrations and real photographs as the types of visuals. Furthermore, based on the sample of the visuals of illustrations and real photographs in the distributed questionnaire, it showed that the target audiences put only a little interest in the colors of the illustrations (bright colors) and photographs (more into dark colors). In relation of the analysis of the selected personas, they were not fond of plain colors. They put more attention only on the attractiveness of the visuals, which made the percentage for the target audience to choose between illustrations and photographs were equal (50\% and 50\%). In accordance, the colors used in the design of the visuals are both bright colors as well as the dark colors together with the types of visuals of illustrations and the real photographs. The use of colors (blue, green, brown and red) based on target audiences' behaviors during the observations, the meaning of the messages and the goals of DaVinci Academie.

The target audiences also expected information that was to the point and directs to the main goals. They preferred information that is not confusing and complicated. Furthermore, one of the target audiences' behaviors during the observation was fun. Therefore, the design of the visuals is made clear, uncomplicated and looks fun as well, aims to communicate the messages of DaVinci Academie easily to the target audiences.
DaVinci has predicted that the target audiences had not recognized and understood the messages of DaVinci Academie yet and the distributed questionnaires also revealed the same result. On that account, the messages that the target audiences thought were not the right messages as DaVinci Academie tried to deliver. Thus, the types of meaning are ap-plied in the design of the visuals, so the messages could be delivered. The visual that signifies the messages has to be located alongside the text of the messages, which is "Personal Leadership and Personal Development" text, to make the target audiences realize that everything is connected.

Since the target audiences thought that travelling would have certain contribution to one's development, it is necessary to combine the visuals of travelling with the visuals that represents the messages and the goals of DaVinci Academie in one whole design of the visuals. Thus, the visuals are made interesting and aesthetically pleasant to attract the target audiences.

\section{Recommendations}

As explained in the section 4.1.4, the entire target audiences did not acknowledge about the messages that DaVinci Academie tried to deliver, which were about Personal Leadership and Personal Development. Some of them stated that they knew the messages that DaVinci Academie had, but apparently it was not the right messages, while some of them said that they knew absolutely nothing about the messages. Thus, it is recommendable for DaVinci to introduce the messages of DaVinci Academie to the target audiences before the training and programs. Briefing is one of the possible ways to achieve the recognition of DaVinci Academie's messages. This would make them have the willingness to strengthen the knowledge of the materials explained in the trainings and programs.

Moreover, DaVinci has already given the concept of travelling right in the beginning of my graduation internship. However, it would be better for DaVinci to choose for several concepts and then put it to find which one would be the best concept that could bring the messages well. This suggestion is not because of the travel journey mismatched the messages, whether it did match, but it would be even better to have such variations of concepts. That way, DaVinci could cogitate about it, and together with the graphic designer, they probably would discover a wider and more various concepts.

Based on the observation done in the training and programs, there was a trainer who explained and taught the target audiences about the materials. 
However, the trainer always forgot and asked the names of the participants a lot during the observations in the training and program. I think, by putting a name board on the table, or wearing a name tag on their shirts would solve this problem.

Furthermore, as it is stated in the section 6.1, the target audiences should get some kind of introduction about the materials that were going to be explained in the training and programs, and the target audiences also need to introduce and get the explanation about the messages that DaVinci Academie had. Distributing an online brochure before the trainings and programs was held would also be a good idea to prepare the target audiences. This way, the target audiences would be well informed about the topics or the materials that would be explained by the trainer and would also understand the essence of the lesson.

However, originally, DaVinci ordered me to put only the explanation and the summary of the materials in the online brochure and there was no explanation and introduction about the messages of DaVinci Academie at all. In my opinion, it is better, and even compulsory to add the explanation of the messages of DaVinci Academie inside the online brochure.
This way, the target audiences would know and understand the messages before the training and programs started, and it would be easier to support and to communicate the messages using the design of the visuals. In addition, this online brochure will be used in the next academic year's trainings and programs, therefore, at this moment, DaVinci only wanted me to create the template for the online brochure without the contents inside it.

Afterwards, the data gathered from the target audiences using observation and distributing questionnaires gave insight for this graduation production; even they were only 8 people. However, it would be even better if the target audiences were at least 40-50 people, because this will be helpful to get the concrete data.

\section{References}

Licastro, D. (n.d.). Travel To Grow. Retrieved April 11, 2016, from http://www.traveltogrow.com/ Mansaray, D. (2012). The Importance of Travel for Personal Development. Retrieved April 11, 2016, from ttp://www.davidmansaray.com/theimportance-of-travel 